\title{
Probiotics as a boon in Food diligence: Emphasizing the therapeutic roles of Probiotic beverages on consumers' health
}

\author{
Feroze Mohamed Khan \\ Department of Food Technology \& Nutrition, Lovely Professional University, Phagwara, \\ Jalandhar (Punjab), India \\ Sonia Morya* \\ Department of Food Technology \& Nutrition, Lovely Professional University, Phagwara, \\ Jalandhar (Punjab), India \\ Vijay Kumar Chattu \\ Department of Medicine, University of Toronto, Canada \\ *Corresponding author. E mail: sonia.morya8911@gmail.com
}

\section{Article Info}

https://doi.org/10.31018/ jans.v13i2.2683

Received: April 22, 2021

Revised: June 2, 2021

Accepted: June 6, 2021

\section{How to Cite}

Khan, F.M. et al. (2021). Probiotics as a boon in Food diligence: Emphasizing the therapeutic roles of Probiotic beverages on consumers' health. Journal of Applied and Natural Science, 13(2), 700 - 714. https://doi.org/10.31018/jans.v13i2.2683

\begin{abstract}
Probiotics are living microorganisms that improve health when eaten or introduced to the body. They have become an essential aspect of everyone's life now due to these products growing health benefits. They contain live bacteria that help our gut maintain good gut microflora and keep us healthy. Lactobacillus and Bifidobacterium are the most used probiotic strains. Everyone knows the importance of these products nowadays and has highlighted the parts that a reader must know about these products and how they affect the human body. This review discusses probiotics, dairy-based probiotics, non-dairy based probiotics and their role in therapeutics. This review has also been elaborated on an essential by-product of the dairy industry, i.e., whey, which has many health benefits and highly recommended for people who are in sports and body-building. While analysing the health benefits of probiotic supplements, there is a lot to discuss,i.e. how and where probiotic products work in our body and provide us with different health benefits. The most common way a probiotic performs is by boosting our immune system and fighting diseases. While looking at the market part of probiotic products globally, it is a multibillion-dollar market mostly based in Europe, where people are more health-conscious. The probiotic market has now frowned worldwide and is one of the most profitable markets in the current world.
\end{abstract}

Keywords: Bifidobacterium, Diarrhoea associated with antibiotics, Lactobacillus, Probiotic beverages, Whey

\section{INTRODUCTION}

Probiotic is a popular term that means "for existence" and is used to describe bacterial associations that have positive impacts on human and animal health (Bagchi, 2014). Understanding the importance of gut flora in human wellbeing and even the idea of probiotic food requires an ecological analysis of gut flora. A person's gastrointestinal tract contains a unique sequence of more than 100-1000 microbial species (GIT). Bacterial cells account for almost half of the wet weight of colonic materials and are 10 times more numerous than the tissue cells that comprise the body. In particular, the stomach contains 103 different bacterial species, and the colon's total microbial population produces roughly 1011-1012 cfu/g (Kerry et al., 2018).
Bacterial invasion of the gut happens during gestation when infants are introduced for the first time to a nonsterile atmosphere.It now shifts and transforms during an individual's health, owing to a complex and varied relationship among the host's food, genome, and climate, as well as antibiotic use. A remarkable time of life empirical improvements in gut microbiota compositions have been reported, including a decrease in the Bacteroidetes/Firmicutes proportion as well as a massive decrease in bifidobacteria in adults above the age of 60 , about the time that the immune system starts to deteriorate (Lloyd-Price et al., 2016). Even so, the configuration of the main intestinal microflora is usually believed to be nearly uniform during adolescence. The effective use of gastrointestinal microflora also known as "colonization resistance" or the "barrier effect," is a 
critical mechanism used by native (autochthonous) gut bacteria to maintain their survival and provide advanced protection against newly ingested microorganisms such as pathogens (Lewis et al., 2015; Pérez-Cobas et al., 2015). As a result, modifying the intestinal microflora to increase the total numbers of "beneficial bacteria," which affect the immune system, digestion, metabolism, and brain-gut connectivity, may be possible (Scott et al., 2015). Some changes in their diversity will lead to a variety of dysfunctions, for which traditional antibiotics have very little effectiveness, owing primarily to the appearance of antibiotic unaffected and sensitive pathogenic microbes (Pamer, 2016). Efforts to solve such a crucial problem by the rising transmission of drugs mechanism to aim sites through nano-encapsulated complex enhancements have been identified as a potential alternative (Qadir, 2015), but these methods tend to be affordable and cumbersome for widespread usage. Consequently, finding an easy, low-cost, responsive, and intrinsic way to enhance host wellbeing is becoming a crucial problem in the modern age. In this way, probiotics help complement the host microflora and offer defences towards several enteric pathogens.

Probiotics have also been shown to increase gut barrier efficiency, which adds to their unique ability to negotiate with pathogenic bacteria for binding to the gut and enhance establishment (Rao et al., 2016). Probiotics also induce, modify, and control the host immune system by activating various genes in localized host cells. They attenuate the secretion of the gastrointestinal hormone and control brain activity as well as good brain axis by bidirectional neuronal signalling (Kristensen et al., 2016). Probiotics play a significant role in promoting intestinal angiogenesis via vascular endothelial growth factor receptor (VEGFR) signalling, which regulates acute and chronic inflammatory in intestinal mucosal tissue impaired by the development of inflammatory bowel disease (IBD) (Bakirtzi et al., 2016; Chen et al., 2013). Probiotics play physiological functions in the host ecosystem's wellbeing by regulating bacteria, and they are also useful in the battle toward obesity (Kobyliak et al., 2016). While probiotics have great promise in nutrient and therapeutic uses, further analysis is needed before they can be used to improve human health, diet, and the control of various disorders. The analysis aims to evaluate the potential benefits of probiotics for promoting human wellbeing, optimizing diet, and regulating specific metabolic conditions or anomalies (Hill et al., 2014). Probiotics are very much safe for human consumption. They do not comprise any harmful toxins or the creation of toxins by these strains of bacteria, which might affect the consumer. The probiotics help support the human body's naturally existing gut microbiota cultures and maintain them. Probiotics can form colonies in the intestinal lumen and survive and function in the upper digestive tract. Probiotics are being used for centuries. The probiotic bacteria strains might temporarily rush the mitosis rate, which might start producing antimicrobial substances and decrease the intestinal transit time while advancing the migrating motor complexes (Von Wright and Axelsson 2019). Probiotics are being used for centuries. The probiotic bacteria strains might temporarily rush the mitosis rate, which might start producing antimicrobial substances and decrease the intestinal transit time while advancing the migrating motor complexes (Banasaz et al., 2002; Halvorsen et al., 2000). For ages, probiotics are being used in fermented dairy products. The uses of these probiotics have shown us that there are plenty of health benefits to human beings. An important role is being played in the standard processing of human digestion and maintaining a healthy state (Kröckel et al., 2006). Due to the nutritional assets, almost every milk product is kept at a shallow temperature; milk and its derivatives are excellent carriers of probiotic strains. The majority of probiotics are gram-positive and catalasenegative (Von Wright and Axelsson, 2019). Probiotics are found in various commercially fashioned dairy products such as sour cream or fresh milk, cheese, and yoghurts. Dairy products show a significant role in bringing probiotic bacteria to the target sites in humans. These products deliver the best appropriate environment for probiotic bacteria growth by supporting their development and life, and many probiotics are based on dairy products. Probiotics have shown us that they offer a wide variety of benefits to the health of mankind. Using specific strain and the particular dosage, we can note the health benefits (Saarela et al., 2006). By adding Lactobacillus species and Bifidobacterium species to the product and increasing the health benefits of fermented products. These bacteria are the most commonly used probiotic colonies of dairy products, with health advantages for humans. The Saccharomyces cerevisiae and the Bacillus species are also extensively used as some probiotic strains (DeVrese and Schrezenmeir, 2008).

\section{MARKET AND PROBIOTICS}

Changes in the population's dietary preferences have resulted in the emergence of a market position for probiotic foods, indicating a superior recognition and shift in consumer behaviours and customs, as customers recognise the importance of probiotics in maintaining health and treating numerous syndromes (KüsterBoluda and Vidal-Capilla, 2017). The worldwide probiotics sector has been expanding in current time's result of rapidly increasing customer demand for healthy foods and healthcare. This has prompted the food industry to create novel probiotic-containing food ingredients and experts to investigate unique probiotic properties and their impact on human health. When delivered 
in sufficient amounts, probiotics are considered live microorganisms that benefit the host. Probiotics have been applied to various food items and integrated into bio-polymeric matrices to create effective food packaging like an additional mechanism for containing foodborne microorganisms, enhancing food quality, and offering health advantages (Espitia et al., 2016). Because of the enormous popularity and growing curiosity in such magical bugs, probiotic items have been willing to develop themselves amongst the masses in a brief period of time as an effective and "natural" way of promoting intestinal health. Probiotics are used as medicinal agents to treat inflammatory, metabolic conditions, including hypertension, atherosclerosis and stroke. Probiotic treatment has been shown to be effective in combating an excess in indigenous microflora in the digestive tract. In this "Nutritional therapy," particular strains of stable microflora are being utilized. Throughout this treatment, probiotics serve both as prevention and a healing factor. Worldwide probiotic production was $\$ 27.09$ billion in 2011 and is forecast to hit $\$ 44.09$ billion in 2018 at a 6.8 percent CAGR (compound annual growth rate) (Raghuwanshi et al., 2018).

Asia-Pacific and Europe account for the majority of global market for probiotics, with Asia-Pacific leading the way with a CAGR of $7 \%$ from 2013 to 2018 . The Asia-Pacific region dominates the probiotics industry, with China and Japan accounting for the majority of sales. In terms of economic sales in Asia, India has grown dramatically. However, between countries in Europe, the United Kingdom and Germany are still the most productive, with a CAGR of $6 \%$ projected from 2013 to 2018. Appetizers are projected to become the most popular category of probiotics, with a market value of $\$ 37.9$ billion by 2018 . The divisions as mentioned earlier, are supplemented by dietary supplements and animal feed, all of which are experiencing rapid development. Milk items are the main product demand for probiotics, with a market value of $\$ 32.2$ billion in 2018 . Though livestock food is a rapid progress market of probiotics, it is predictable to beat US $\$ 3$ billion by 2018. The main impediment to consumer development is the rising cost of goods, the development of tradition, and the absence of inventory standardization (Raghuwanshi et al., 2015). In India, the demand for probiotics distributed in probiotic sachets, capsules, and other pharmaceutical supplements is greater than that for probiotics offered in the form of probiotics sachets, capsules, and other pharmaceutical preparations. Due to the lack of regulatory requirements, many bogus and unreliable probiotic products with misleading assertions are coming into the sector, leaving customers in the dark about the acceptability of probiotics items in many Asia-Pacific countries India. Probiotic medicines have a lucrative niche, and have been recognized by a variety of domestic pharmaceutical firms.
So, several food producers have taken steps to broaden their current business exposure and penetrate the emerging probiotic business (Ambalam et al., 2016; Arora and Baldi, 2015).

The most important probiotics in the market are Actimel, Yakult and ProViva. The species of bacteria in Actimel is Lactobacillus casei of the strain DN114001. Yakult have Lactobacillus casei species, and the strain is Shirota. ProViva uses $L$. plantarum species, and the strain is $299 \mathrm{v}$.

\section{APPLICATIONS IN THE FOOD INDUSTRY}

Food products with beneficial effects, including proper diet, were developed as a result of advances in functional food awareness. Market involvement in functional foods, especially those comprising probiotics, has grown during the past 20 years. The occurrence of probiotics in these foods adds health benefits to them. This has led to the creation of different types in a new generation of 'probiotic health' foods by analysing different food products for its probiotic applications. This section about probiotic products' food applications summarises the mutual claims of probiotics in food products (Song et al., 2012). Probiotics endure movement across the gastrointestinal tract and reside in the intestine while they actually sustain life in the fermentation medium; they enhance the composition of the intestinal microbiota of people who eat them regularly (Khalesi et al., 2019).

\section{Beverages}

Beverages can be classified in different ways, such as based on alcohol and dairy. On the basis of alcohol, the beverages are divided into two categories. They are alcohol and non-alcohol. Figure 1 based on dairy, the beverages are divided into two categories, dairy and non-dairy. In the same way, probiotic beverage can be classified into two groups' viz. dairy-based probiotics beverages and non-dairy based probiotic beverages. Symbiotic foods are foods or drinks that contain both probiotics and prebiotics. As a result, in probiotic foods, the proper selection of food matrices as possible carriers of probiotics is critical. It is important to keep probiotics alive during processing and storage to keep their concentrations at high levels (106-107 CFU/ml or $\mathrm{g}$ of food (Valero et al., 2020). In this review, the main focus is intended on probiotic beverages. The worldwide functional beverage industry is an increasing segment of the food sector, as current health-conscious customers show an increasing demand for foods that can improve wellbeing and decrease disease risk (Leatherhead food research, 2011). Many areas around the world are indigenous to the fermentation of milk, cereals, as well as other substrates to manufacture drinks with health-promoting qualities. Fermented 
milk, which belongs to dairy beverages, is created in several areas of the world. Fermented dairy products may be produced from different milk sources of milk (or skimmed milk). The fermented milk mostly consists of lactic acid bacteria (LAB). Another important class comes in the non-dairy category, mostly using cereals, which are common in tropical areas and, in general, on the African continent. The fermentation of grains, including maize, barley, millet, oats, wheat, rye, rice or sorghum, is done to produce this beverage (AkpinarBayizit et al., 2010).

Fig. 1 shows the classification of beverages. The beverages are classified into two major categories as alcoholic and non-alcoholic beverages. Non-alcoholic beverages are further classified into carbonated and noncarbonated beverages. Carbonated beverages consist of soda, coco-cola, and tonic water. Non-carbonated beverages include fruit juices, tea, and coffee. The alcoholic beverages have been classified into fruit/sap products or grain products; and again classified into non-distilled and distilled category. The grain-based products of non-distillation have been known as beer and distilled ones as whisky.

\section{Dairy-based probiotic beverages}

Nowadays, consumers are much aware of looking after their health and maintaining them as never before. There are several reasons for accepting "food as medicine" due to increased regular life span length of people than earlier in the countries in the developing and developed category (Kechagia et al., 2013). The addition of probiotics into milk products may help accept harsh gastro-intestinal situations easier than non-carriers products, even as buffering milk and milk fat may preserve probiotics in certain situations by minimizing high access to brutal environments. Ice cream and other dairy products high in milk fat are observed to become more beneficial in increasing probiotic survival rate and bile acid resistance (Ranadheera et al., 2017). Functional foods are nutrient compounds that have been fortified, nourished, or modified to support the body. These efficient products of dairy have an essential place inside the functional food category, consisting of about $40 \%$ of the probiotic market. A considerable amount of functional dairy products is now fermented products. The global dairy beverage markets are a very active part of the dairy industry. The global dairy beverage markets are supposed and predicted to touch a market worth 14 billion US Dollars by the end of 2021, also excluding the kefir and buttermilk, which are traditional dairy beverages (Özer and Kirmaci, 2008). Functional foods are classified as fortified, enriched, or enhanced food compounds that positively benefit the human body. These efficient products of dairy have an essential place inside the functional food category, consisting of about $40 \%$ of the probiotic market. A considerable amount of functional dairy products is now fermented products. The global dairy beverage markets

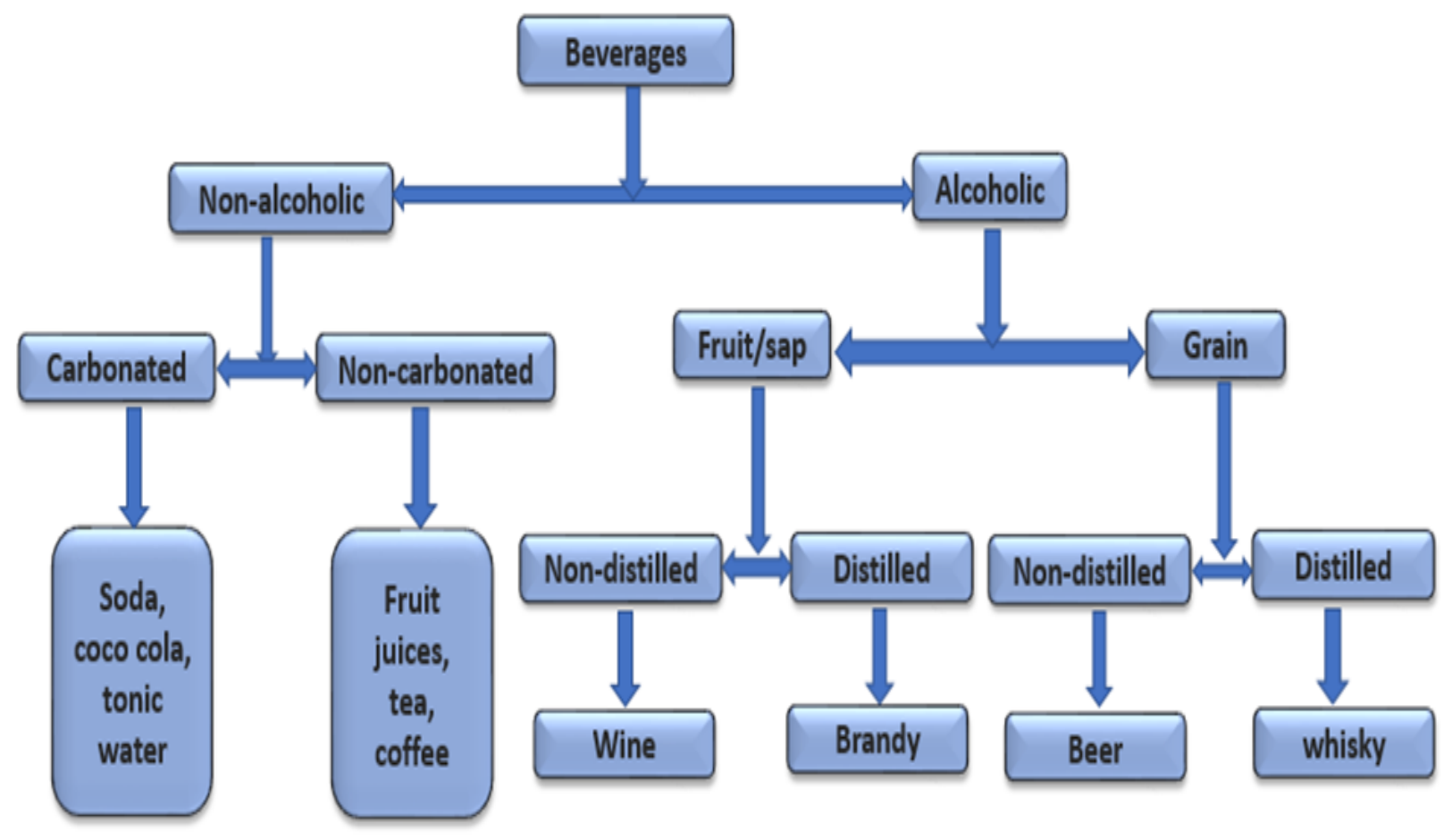

Fig. 1. Classification of beverages . 
are a very active part of the dairy industry. The global dairy beverage markets are supposed and predicted to touch a market worth 14 billion US Dollars by the end of 2021, also excluding the kefir and buttermilk, which are traditional dairy beverages (Hasler et al., 2002). There is a long history of uses of cheese and its byproducts in dairy-based beverage production units. The cheese whey was being used to produce whey powders and whey concentrate, which are low value-added products for commercial purposes, until the last two decades. The cheese whey has been developed into a desirable product after understanding its high nutritional capacity (Onwulata and Tomasula, 2004). Functional drinks now contain beverage supplements or are enriched with active ingredients, and they occupy an important place in the dairy-based markets (Özer and Kirmaci, 2010).

Another example is Acidophilus milk. The strain used is $L$. acidophilus. They are known for Anticarcinogenic properties and improved lactose utilization. It also has a chemo-preventive effect, especially against colon cancer and lactose intolerance treatment. The fortification of acidophilus milk with different additives has now increased the taste and health benefits. Many other research has found testimony that acidophilus dairy intake has beneficial effects such as regulating serum cholesterol levels avoiding intestinal pathogen disorders, chemotherapeutic effects, especially toward colon cancer; the lactose digestion in lactose-intolerant patients, antiinflammatory impact towards irritable bowel syndrome, and balancing intestinal microbiome (Aryana and Olson, 2017; Markowiak and Slizewska, 2017). Acidophilus milk retains its natural flavour as well as flavours that form as a result of enzymatic degradation throughout fermentation. Proteolysis is among the major enzymatic degradations, along with lipolysis and glycolysis that are accountable for the sensory effects of fermented milk (Smit et al., 2005).

\section{Non-dairy based probiotic beverages}

In the method of fermented milk, yoghurt, and other products, probiotic products are frequently marketed with an upward increase in the consumers across developed and developing countries. Vitamins, enzymes, minerals, and bioactives are abundant in fruit and vegetable beverages. They are a decent alternative to dairy matrices, as well as a good option for the entire human population; since they are hydrating, refreshing, and have appealing flavours (Granato et al., 2010). Vegetarian probiotic products have a high demand. The cholesterol content and lactose intolerance are two significant drawbacks of fermented dairy products (Heenan et al., 2004). Fruit juice has been suggested as an ideal substrate for the manufacture of non-dairy probiotic drinks. In addition to that, fruit juices contain nutritious additives such as vita- mins, enzymes and polyphenol. Specifically, they comprise many sugars and nutrients essential for the growth of probiotics (Ding and Shah, 2008).

Example; Hardaliye. It is a lactic acid fermented beverage made by naturally fermenting red grapes or fruit juices with crushed mustard seeds and benzoic acid. This beverage is made in the Turkish region. It is recognized that since ancient times it has been produced and eaten. The etheric oils in mustard seeds affect yeasts and also impart flavour to the finished product. By influencing yeast, benzoic acid inhibits or reduces alcohol in it. After fermentation, the tough living is preserved at $4^{\circ} \mathrm{C}$ and eaten whether fresh or mature. Lactobacillus paracasei subsp. paracasei, L. casei subsp. pseudoplantarum, L. brevis, L. pontis, L. acetotolerans, $L$. sanfransisco, and $L$. vaccinostercus are present in the beverages. This classification enabled the collection of suitable strains for the production of tough living utilizing pasteurized or sterile processed grape juices (Wang et al., 2009).

\section{Cereal based probiotic beverages}

Cereal-based fermented drinks are a significant category of fermented beverages. They are common in tropical areas and Africa. Fermented varieties such as corn, millet, barley, oats, rye, wheat, rice, or sorghum are being used (Marsh et al., 2014). Non-alcoholic beverages are produced by lactic acid fermentation, whereas alcoholic beverages are produced by lactic acid and alcoholic fermentation (Setta et al., 2020). These beverages provide health benefits to the consumer due to living microbes (Verbeke et al., 2009). A symbiotic functional drink produced from oats was produced by mixing a probiotic starter culture and a whole-grain oat substrate. Oats and barley have the highest betaglucan content, which is recognized as the primary functional component of cereal fibers. This compound has been shown to have a hypocholesterolemic impact, likely to lead to a $20-30 \%$ reduction in LDL cholesterol and a decreased risk of cardiovascular disease (Muyanja et al., 2003).

\section{Whey based probiotic beverages}

Nowadays, changing time and growing industries working in new ways, such as eco-friendly processes, have transformed the changes such as not discarding the whey outlets into the streams and other appropriate sewage options. Subsequently, the search for a new method of using whey has begun again. Whey is a byproduct obtained during the conversion of milk into chhana and paneer. It is estimated that around $4-5 \%$ of the total milk produced is converted into these forms. Whey is a nutritious by-product containing $45-55 \%$ milk nutrients (Morya et al., 2017a , b). Although whey is a by-product, whey ingredients have a wide range of nutritional and health-promoting properties. Whey and 
whey proteins have an antioxidant function, antimicrobial, immune-stimulating, anticancer effects, reduce blood pressure, reduction in risk of cardiovascular disease, anti-osteoporosis, and regulate satiation ( $\mathrm{Ha}$ and Zemel, 2003; Kassem, 2015; Khan et al., 2015). Lactoferrin, a protein present in dairy whey that combines iron, has antibacterial properties. It eliminates iron from bacteria. Lactoferrin is a powerful antiviral agent. It interacts with viral infections directly, hindering virus replication and their binding ability to colonic epithelial cells. Lactoferrin in whey has antibacterial properties due to its ability to bind iron, making it inaccessible to pathogens, thus inhibiting their metabolism and development (Chizhayeva et al., 2020). Lactoferrin's immune activation advantages also aid in viral reduction (Troost et al., 2001). Lactoperoxidase is another essential protein component of whey and a natural defence against infectious microorganisms and viruses. Lactoperoxidase catalyses the peroxidation of thiocyanate to hypothiocinate, a powerful oxidant that destroys bacterial cell membranes (Chizhayeva et al., 2020).

Cheese whey was used as a beverage in human nutrition, mostly for therapeutic uses by the industries, which can be agreed upon for an assortment of human illnesses. In the middle Ages, whey was recommended by many doctors for a wide range of diseases (Susli, 1956). The whey proteins are a rich source of amino acids that can metabolize directly into the muscle tissue just like lactose; because of this, property athletes can use them as sports drinks during periods of exercise and resistance training (Pescuma et al., 2010). They also include lactoferrin, glycol macro-peptides, phenylalanine, and alpha-lactalbumin. Due to lactoferrin content, whey beverages can be valuable for children and babies. It benefits from iron absorption from food and keeps the pathogens from sticking to the intestinal walls. Also, it is beneficial for elderly people as it may help in the absorption of calcium. Whey beverages help patients affected by phenylketonuria, as whey is a rich source of energy micronutrients (Jelicic et al., 2008). Numerous whey-based drinks, including plain, alcoholic, carbonated, and fruitflavoured versions, were produced and widely sold worldwide. Beverage makers can readily incorporate the advantages of whey protein into various items, such as highly soluble in a $\mathrm{pH}$ range of 2 to 10 , provides safe and clear drinks even in a $\mathrm{pH}$ range of 3.0 to 3.2 (Gottschalk, 2005). Whey protein present in the milk is an important source of essential as well as non-essential amino acids. Studies have proved that about nine essential amino acids are found in whey protein (Morya and Danquah, 2018).

Antimicrobic, antifungal and antiviral properties of whey: Immunoglobulins (Igs), glycomacropeptide (GMP), lactoferrin (Lf) and sphingolipids are all special components found in milk whey that have antimicrobial and antiviral properties. Since passing through the stomach and small intestine, both of these compounds are able to survive and have a biological impact on the large intestine. Lactoferrin in whey has antibacterial properties due to its ability to bind iron, making it unavailable to pathogens, thereby inhibiting metabolism and development. Lactobacilli can use iron bound to lactoferrin at the same time. Lactoferrin and lactoferricin suppress a wide variety of microorganisms, including Gram-positive bacteria, yeast, and fungi. They also stop food pathogens like Escherichia coli and Listeria monocytogenes from growing. Lactoferrin also has antiviral properties; it interacts directly with the selected viral pathogen, inhibiting virus replication and the ability of the virus to bind to epithelial cells of the large intestine (Chizhayeva et al., 2020).

Example: Whey cheese. The bacterial strain present is Bifidobacterium sp. culture. They are primary food supplements used by athletes because it provides them with bioactive peptide and essential amino acids. It improves physical performance and muscle protein synthesis. This product is also linked to a reduced risk of asthma, coagulopathy, stroke, and cancer outbreaks (Sultan et al., 2018). Probiotic whey drinks enhance individual health by reducing serum cholesterol and blood pressure, improving lactose intake, having anticarcinogenic qualities and stimulating the immunity system (Enujiugha and Badejo, 2017).

Whey based probiotic beverage has many health benefits, which are shown in Fig. 2.

\section{HEALTH BENEFITS OF PROBIOTICS}

It is believed that some useful bacteria consumed inside the human body through food can improve the health of customers of these foods by moderating their gut microflora. Meanwhile, a bond between these increased amounts of beneficial bacteria and beneficial biological effect is yet to be known in the gut flora (Plaza et al., 2014). Several studies are nearby in the literature bothering the likely health influences of the probiotic organisms on humans. In the 1950s, the PUBMED had 20,000 articles being published about probiotics, and then there were clinical trials of approximately 2,200 in numbers. The area of most focused studies was the immune system. Its antimicrobial activity using vitro cell cultures in dairy products including yogurt, cheese, and dairy-based beverages, the health impacts of probiotic products were broadly investigated (Song et al., 2012). The definition of "optimal nutrition" has evolved to include essential nutrients and non-nutrients that play a role in physiological and biochemical functions and increase the consistency of human diets as scientific knowledge and techniques have advanced 


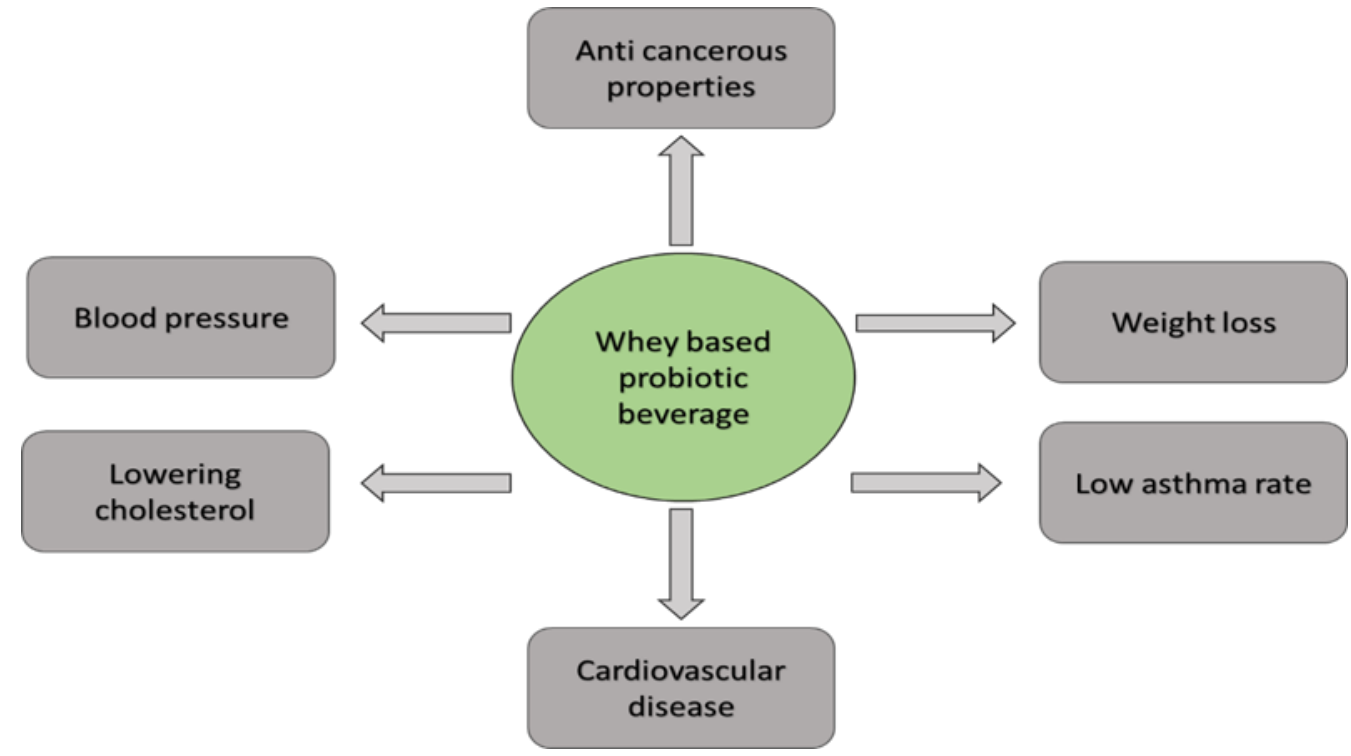

Fig. 2. Important health functions of whey based probiotic beverages.

(Aguiar et al., 2019). Assess probiotic effects of dairy products on humans are parts as there could not be much human trials conducted. Hypocholesterolaemia effect of the probiotic strain were studied mostly using the in vitro models. The findings have revealed the assimilation of cholesterol takes place by the probiotic cell attachment to the cholesterol, and it is studied that cholesterol can effectively be removed by probiotics (Bhat and Bajaj, 2020; Lin and Chen, 2000). When consumed, probiotic cheese is found to improve the cases of humans' cardiovascular health measures potentially; for example, the cardiovascular parameters of the model animals were positively affected by the regular intake of the probiotic Minas cheese. The immune-system responses of these mice were not affected by the ingestion of probiotic products. Their blood lipid profiles were still highly improved along with the rat's antioxidant defences (Moura et al., 2016). Recent studies showed that probiotic cheese intakehad prohibited the development of kidney stones in these Wistar rats (Cordeiro et al., 2018). Probiotic bacteria have been shown to enhance the immune system and prevent gut, vaginal, and urogenital infections, diarrhoea, and gastritis by inhibiting enteric and food-borne microbial pathogens (Walsh et al., 2010). Fermented milks have antihypertensive qualities and improve immune, reduce cholesterol, and generally lower blood pressure. They have been shown to help cure IBS and relieve constipation in recent human trials (Tabbers et al., 2011). Many probiotic strains were identified to inhibit Helicobacter pylori in vitro, which has been linked to gastritis, abdominal carcinoma, gastric ulcer, and lymphomas. Any clinical trials have reported this adverse influence on Helicobacter pylori, which appears to be independent of the bacteria's survival (HamiltonMiller et al., 2003).
Prevention of diarrhoea associated with antibiotics Some slightdiarrhoeais the side effects of therapy using antibiotics. This happens due to the overgrowth of the pathogenic bacteria strain. This is caused by cytotoxic strains, Clostridium difficile, which may have emerged after antibiotic use. The complications that occur are abdominal distension, fever, vomiting, and leucocytosis. If it is led untreated, then it can lead to perforations and toxic megacolon. Probiotics were used in medical practice for diagnosis with $S$. boulardii and $L$. rhamnosus (Hempel et al., 2012). Several studies mention that these probiotics are associated with reducing the antibiotic diarrhoea infection rate (McFarland 2006; Sazawal et al., 2006).

\section{Probiotics associated with the prevention of allergy} Probiotics can provide an alternative to stimulate the immune system for such situations. Probiotics help to regulate the Th1/Th2 balance by suppressing Th2 responses and shifting them to Th1, preventing allergies. Probiotics are linked to a reduction in inflammation by raising butyrate development and induction of tolerance by increasing the ratio of cytokines, which lowers serum eosinophil levels and the expression of metalloproteinase-9, which controls inflammation.

\section{Diarrhoea caused due to an infection}

The most significant and well-known health advantage of probiotic bacteria is the diagnosis and prevention of severe diarrhoea. Acute infantile diarrhoea is most common and is caused by rotavirus. The addition of probiotics to baby foods has shown to be beneficial and effective in battling rotavirus infection and treating it. Probiotics such as $L$. rhamnosus $G G, L$. reuteri, $L$. casei Shirota, and $B$. animalis Bb12 were shown in experiments to shorten the time of diarrhoea caused by rota- 
virus. It plays a role in enhancing the immune response and inactivating the viral particle. Probiotics have also been shown to be effective in the treatment of traveller'sdiarrhoea. There was a $15 \%$ reduction in the disease administered with the probiotics on the trip (Leung et al., 2019).

\section{Lactose Intolerance}

It is the deficiency in which the person cannot hydrolyse lactose into monosaccharides glucose and galactose. People with lactose intolerance may experience diarrhoea, abdominal pain and discomfort after consuming milk or milk products. The observations indicated that probiotic yoghurt fortified with $L$. acidophilus and Bifidobacterium sp. could improve lactose intolerance complications and HBT healthily and effectively, implying that this probiotic should be prescribed as a medication of preference for lactose intolerance sufferers (Masoumi et al., 2021).

\section{SIGNIFICANT CLINICAL APPLICATIONS OF PROBIOTICS}

\section{Anti-obesity activity of probiotics}

It has been discovered that transplanting the gastrointestinal microflora of a fat rodent into germ-free rodents will mimic the fatty phenotype and may make the mice quite efficient at absorbing energy from food and promoting lipogenesis. Probiotics have certain physiological roles that affect the being of the host ecosystem by controlling microbiota. Weight loss is aided by thermogenesis and lipolytic reactions, which are elicited by activating the sympathetic nervous system (SNS) (Karimi et al., 2015). Lactobacillus gasseri BNR17 strains have characteristics that suppress the rise in adipocyte tissue, which is the key source of leptin and adiponectin and reducing leptin release. Some bacteria including Lactobacillus casei, Lactobacillus acidophilus and Bifidobacterium longum have been found to have hypo-cholesterolemic effect (Kerry et al., 2018).

\section{Angiogenic activity of probiotics}

Angiogenesis is a cellular response to regenerate damaged tissues. It is a wound healing process of the body. New channels arise from pre-existing forms by promoting the recruiting of inflammatory cells and the production of cytokines, matrix-degrading enzymes, and chemokines (family of small cytokines). Disrupted angiogenesis has a significant effect on significant health conditions such as cancer diabetic retinopathy and CD. Probiotic strains such as lactobacilli and bifidobacterium has significant function in Celiac disease by breaking gluten protein and eliminate ability to elicit immune response, reviewed by Kumari and Morya (Kumari and Morya, 2021).

Probiotic yeast that is non-pathogenic such as $S$. bou- lardii has been studied and found to have protection against intestinal injury and inflammation. The potential mechanism of probiotics has been detected by which the process of angiogenesis may include the alteration of inflammatory cytokine summaries with reduction of visceral hypersensitivity and stress response. The molecular mechanisms by which probiotics create these favourable effects on the tissue still remain unclear (Chen et al., 2016; Folkman, 2006; Folkman, 2007).

\section{Probiotics' anti-cancer function}

Cancer is a dreadful disease that affects individuals all over the world, with 14 million new cases and 8.2 million cancer-related deaths recorded in 2012. There are so many researches going on the cancers to find a way to tackle them easily without the loss of lives and make public awareness to people about cancer (Vidya and Thiruneelakandan, 2015). Many new drugs have been discovered with intense research in the field of nanotechnology and biotechnology, but there are limitations due to the side effects (Gayathri and Rashmi, 2016). L. fermentum NCIMB-5221 and -8829 probiotic strains were investigated and they are highly effective in inhibiting colorectal cancer cells and encouraging normal epithelial colon cell growth by SCFA development (ferulic acid). Some other study found that the probiotic strains $L$. acidophilus LA102 and L. casei LC232 had good cytotoxic and anti-proliferative action in vitro toward two colorectal cancer cell lines (Kahouli et al., 2015). Although probiotic strains might play a vital part in neutralizing the cancer cells, they are mostly limited to in vitro tests. If these tests are moved to in vivo methods, then only the animal trials could be possible (Awaisheh, 2016; Kerry et al., 2018).

\section{Probiotic anti-allergy behaviour}

The risk of allergic diseases for people around the world is severe. The positive functions of probiotics that prevent and control allergic diseases have been shown in recent times. In recent in-vitro tests with the synthesis of interleukin 12 and interferón-gamma in their host, probiotic bacteria like L. plantarum L67 have shown to be successful combating allergy related disorders (Song et al., 2016). Some other analysis found that $L$. plantarum 06CC2 substantially decreased allergic effects and overall immunoglobulin E, ovalbumin-specific immunoglobulin $E$, and histamine rates in the sera of ovalbumin-sensitized rodents. L. plantarum 06CC2 has been shown to greatly increase interferon-g and interleukin-4 secretions in mouse spleen cells, which are liable for allergic conditions (Takeda et al., 2014; Kerry et al., 2018).

\section{Potential of probiotics in covid-19 timeline}

In January 2020, the World Health Organization (WHO)

announced an emergency situation due to an outbreak 
Khan, F.M. et al. / J. Appl. \& Nat. Sci. 13(2), 700 - 714 (2021)

Table 1.Probiotic drinks with dairy and non-dairy sources and functional properties.

\begin{tabular}{|c|c|c|c|c|}
\hline Category & Product & Strain & Function & References \\
\hline \multicolumn{5}{|c|}{ Dairy based probiotic beverages } \\
\hline \multirow{6}{*}{$\begin{array}{l}\text { Milk based } \\
\text { probiotic } \\
\text { beverages }\end{array}$} & Kefir & $\begin{array}{l}\text { Lactococcus, Lactobacillus, } \\
\text { Leuconostoc, }\end{array}$ & $\begin{array}{l}\text { Stimulation of the immune } \\
\text { system, lowering cholester- } \\
\text { ol, and anti-mutagenic ef- } \\
\text { fects }\end{array}$ & $\begin{array}{l}\text { Laureys and De } \\
\text { Vuyst, 2014; Guzel } \\
\text {-seyd et al., } 2011\end{array}$ \\
\hline & Shubat & $\begin{array}{l}\text { Lactobacillus casei, Strepto- } \\
\text { coccus thermophilus }\end{array}$ & $\begin{array}{l}\text { Provide additional nutrition- } \\
\text { al advantages in relation to } \\
\text { basic nutrition. }\end{array}$ & Shori, 2012 \\
\hline & $\begin{array}{l}\text { Acidophilus } \\
\text { milk }\end{array}$ & Lactobacillus acidophilus & $\begin{array}{l}\text { Anti-carcinogenic proper- } \\
\text { ties, and improved lactose } \\
\text { utilization. }\end{array}$ & Vedamuthu, 2006 \\
\hline & $\begin{array}{l}\text { Koumiss- } \\
\text { Kumiss }\end{array}$ & $\begin{array}{l}\text { Lactobacillus acidophilus } \\
\text { Lactobacillus delbrueck- } \\
\text { isubsp. Bulgaricus }\end{array}$ & $\begin{array}{l}\text { It may be used to treat dia- } \\
\text { betes, tuberculosis, lung } \\
\text { disease, and gynecological } \\
\text { disorders. }\end{array}$ & Marsh et al., 2014 \\
\hline & Bifidus milk & $\begin{array}{l}\text { Bifidobacteriumbifidumand- } \\
\text { Bifidobacteriumlongum }\end{array}$ & $\begin{array}{l}\text { Bifidus milk is used for the } \\
\text { cure of gastrointestinal and } \\
\text { liver diseases. }\end{array}$ & Yerlikaya, 2014 \\
\hline & $\begin{array}{l}\text { Acidophilus- } \\
\text { Bifidusmilk }\end{array}$ & $\begin{array}{l}\text { Lactobacillus acidophilus } \\
\text { andBifidobacterium ssp. }\end{array}$ & $\begin{array}{l}\text { Good for gastrointestinal } \\
\text { tract. }\end{array}$ & Yerlikaya, 2014 \\
\hline
\end{tabular}

\section{Non-dairy based beverages}

\begin{tabular}{|c|c|c|c|c|}
\hline \multirow{3}{*}{$\begin{array}{l}\text { Fruit based } \\
\text { probiotic } \\
\text { beverages }\end{array}$} & Hardaliye & Lactobacillus spp. & $\begin{array}{l}\text { Potential health out- } \\
\text { comes include metabolic, } \\
\text { endocrine, cardiovascu- } \\
\text { lar, immune, and nervous } \\
\text { system effects }\end{array}$ & $\begin{array}{l}\text { Wang et al., } 2009 \\
\text { Salmeron et al., } \\
2015\end{array}$ \\
\hline & Gefilus & Lactobacillus rhamnosus GG & $\begin{array}{l}\text { Boost's immunity and } \\
\text { increases the gut health. }\end{array}$ & Aspri et al., 2020 \\
\hline & Mandarin juice & $\begin{array}{l}\text { Lactobacillussalivariusspp, } \\
\text { salivariu CECT } 4063\end{array}$ & $\begin{array}{l}\text { Mandarin oranges are } \\
\text { high in vitamin } \mathrm{C} \text { and } \mathrm{A} \text {. } \\
\text { They also have dietary } \\
\text { fiber, as well as nutrients } \\
\text { like potassium and man- } \\
\text { ganese. }\end{array}$ & Aspri et al., 2020 \\
\hline \multirow{3}{*}{$\begin{array}{l}\text { Whey based } \\
\text { probiotic } \\
\text { beverages }\end{array}$} & Whey cheese & Bifidobacterium sp. & $\begin{array}{l}\text { It is nutritional, emulsifier } \\
\text { and has sensory proper- } \\
\text { ties. }\end{array}$ & Lappa et al., 2019 \\
\hline & $\begin{array}{l}\text { Grape-flavoured } \\
\text { whey drink }\end{array}$ & Lacticasei bacilluscasei & $\begin{array}{l}\text { Products present great } \\
\text { hypoglycaemic potential }\end{array}$ & Barros et al., 2020 \\
\hline & $\begin{array}{l}\text { Whey-sorghum } \\
\text { based probiotic } \\
\text { drink }\end{array}$ & $\begin{array}{l}\text { Lactobacillus acidophilus, Lac- } \\
\text { tobacillus casei, Lactobacillus } \\
\text { rahmnosus }\end{array}$ & $\begin{array}{l}\text { Product with nutritional } \\
\text { and excellent organolep- } \\
\text { tic properties. }\end{array}$ & Morya et al., 2017a \\
\hline
\end{tabular}

Contd........... 
Table 1. Contd.........

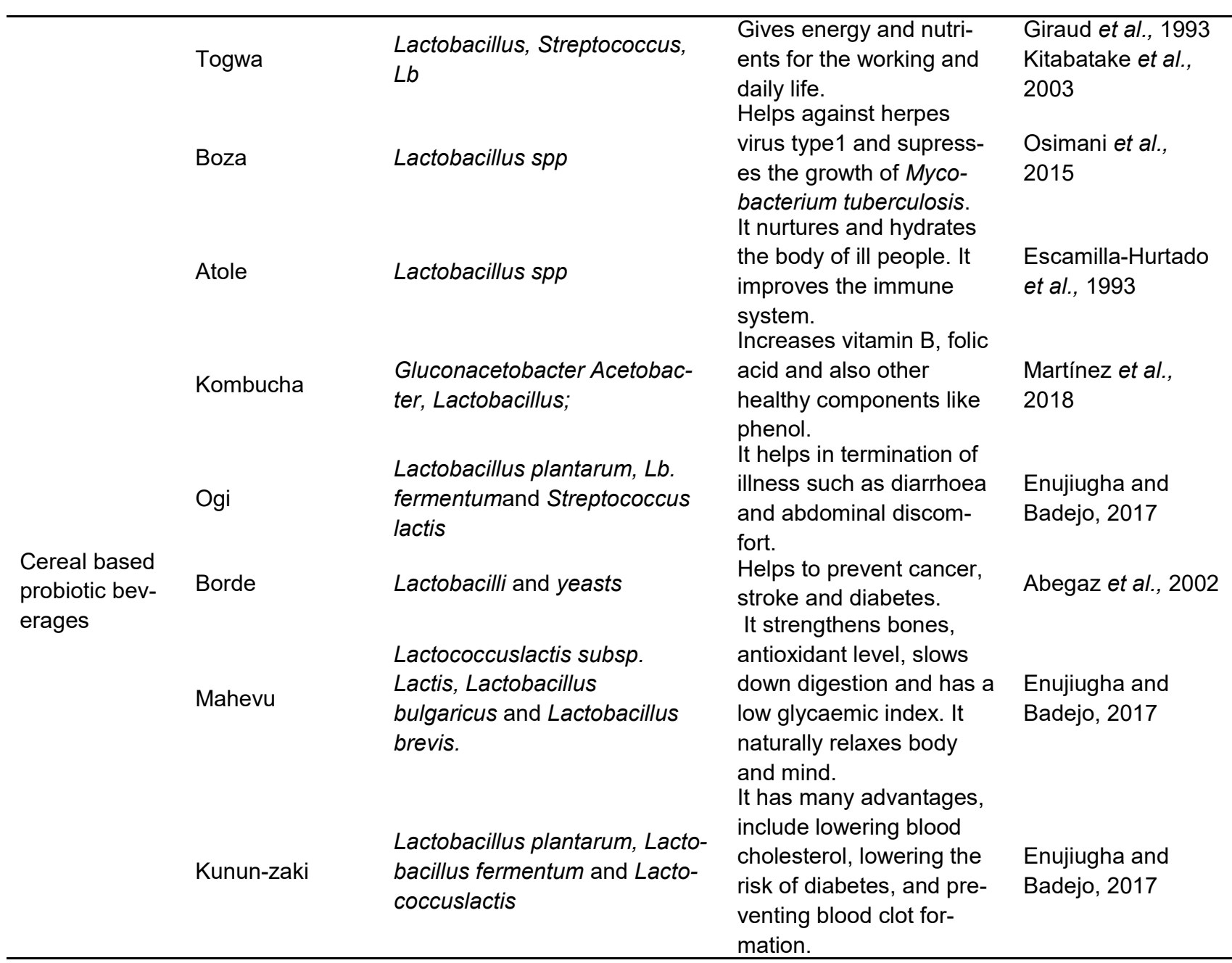

of infection by a new kind of virus in the coronavirus community. SARS-CoV-2 is the name given to this current coronavirus strain (Docea et al., 2020). A COVID19 disease preventive approach also includes antiviral, anti-shock, anti-hypoxia, anti-infective, and microbiota balance protection. To maximize the therapeutic outcome, each received multidisciplinary and individualized therapy (Islam et al., 2020). After getting affected with covid 19 infections, in bifidobacterium and lactobacilli in the intestine there has been a significant reduction in sufferers. They were given probiotics and prebiotics to help restore health and reduce secondary infections in the body. In an animal analysis sample, $L$. plantarum strain on the intestinal mucus prevented epithelial cell infections with corona viruses (Infusino et al., 2020).

\section{Future prospects of probiotics}

It has estimated that the probiotics industry will rise to $\$ 12$ billion in 2026. There are also estimates to increase demand for fermented dairy products to 2.45 billion dollars by 2023 . Usage of fermented milk products has grown dramatically, and between 1998 and
2003, it grew more than six-fold (Pinto et al., 2017). The highest amount of foods produced currently has dairy, accompanied by bakery and cereal. It has been growing at 14-15 per cent per year (Fernandesa et al., 2020). Beverages are the most appropriate ready-to -eat product in the market. There is a need to conduct human studies in future researches in field of probiotics to find out which probiotic strain with the required dose quantity with the highest efficacy and for which disease (Kechagia et al., 2013). Their safety measure with limitations has also need to be demonstrated. Regulatory bodies' status must be set for the probiotics as probiotic foods need to be recognizing at the international level. Food labels of probiotic products must be clearly mentioned for the efficacy, safety and health claims validation.

\section{Conclusion}

This review has focused on numerous health benefits of probiotics, like boosting the immune system, gut health, fighting against diseases, etc. Probiotics exhibit anti-allergic, anti-carcinogenic, angiogenic, improve 
digestion of lactose in lactose intolerant etc. Even animal studies show the positive impact of probiotics on Covid-19 by preventing the infection in epithelial cells. However, for checking the impact on humans still, studies need to be done. With adequate substrate concentration to function properly in a probiotic product and eventually to involve in human health, the vast area of functional foods has been covered. Probiotics can be consumed in many forms of food (dairy and non-dairy probiotic beverages; cereal-based, fruit-based, and whey-based probiotics, etc.). Besides boosting immunity, it helps in the proper functioning of the cardiovascular system and provides antimicrobial properties. The probiotic market in the world's scenario is one of the good money-making factors. With the rising share of probiotic beverages, the European countries are the current leads in the world. The continuous innovations improved the taste and flavours of probiotic products hence catching more consumers in this market. The current probiotic market has a high scope as it is always a potential factor for scientists and new researchers.

\section{ACKNOWLEDGEMENTS}

The authors wish to acknowledge Lovely Professional University for supporting this study.

\section{Conflict of interest}

The authors declare that they have no conflict of interest.

\section{REFERENCES}

1. Abegaz, K., Beyene, F., Langsrud, T., \& Narvhus, J.A (2002). Indigenous processing methods and raw materials of borde, an Ethiopian traditional fermented beverage. Journal of Food Technology in Africa, 7, 59-64. https:/l doi.org/10.4314/jta.v7i2.19246

2. Aguiar, L. M., Geraldi, M. V., Cazarin, C. B. B., \& Junior M. R. M. (2019). Functional food consumption and its physiological effects. In Bioactive compounds (pp. 205225). Woodhead Publishing. http://doi.org/10.1080/1040 8398.2020.1844140

3. Akpinar-Bayizit, A., Yilmaz-Ersan, L., \& Ozcan, T. (2010). Determination of boza's organic acid composition as it is affected by raw material and fermentation. International Journal of Food Properties, 13(3), 648-656. https:// doi.org/10.1080/10942911003604194

4. Ambalam, P., Raman, M., Purama, R. K., \& Doble, M. (2016). Probiotics, prebiotics and colorectal cancer prevention. Best Practice \& Research Clinical Gastroenterology, 30(1),119-131.https://doi.org/10.1016/j.bpg.2016.0 2.009

5. Arora, M. \& Baldi, A. (2015). Regulatory categories of probiotics across the globe: a review representing existing and recommended categorization. Indian Journal of Medical Microbiology, 33(5), 2.
6. Aryana, K. J., \& Olson, D. W. (2017). A 100-Year Review: Yogurt and other cultured dairy products. Journal of Dairy Science, 100(12), 9987-10013.https://doi.org/10.3168/ jds.2017-12981

7. Aspri, M., Papademas, P., \& Tsaltas, D. (2020). Review on non-dairy probiotics and their use in non-dairy based products. Fermentation, 6(1), 30.https://doi.org/10.3390/ fermentation6010030

8. Awaisheh, S. S., Obeidat, M. M., Al-Tamimi, H. J., Assaf, A. M., El-Qudah, J. M., \& Rahahleh, R. J. (2016). In vitro cytotoxic activity of probiotic bacterial cell extracts against Caco-2 and HRT-18 colorectal cancer cells. Milk Science International-Milchwissenschaft, 69(7), 33-37.https:// doi.org/10.25968/MSI.2016.7

9. Bagchi, T. (2014). Traditional food \& modern lifestyle: Impact of probiotics. The Indian Journal of Medical Research, 140(3), 333.

10. Bakirtzi, K., Law, I. K. M., Xue, X., lliopoulos, D., Shah, Y. M., \& Pothoulakis, C. (2016). Neurotensin promotes the development of colitis and intestinal angiogenesis via Hif1a-miR-210 signaling. The Journal of Immunology, 196 (10), 4311-4321.https://doi.org/10.4049/jimmunol.1501443

11. Banasaz, M., Norin, E., Holma, R., \& Midtvedt, T. (2002). Increased enterocyte production in gnotobiotic rat's monoassociated with Lactobacillus rhamnosusGG. Applied and Environmental Microbiology, 68(6), 3031-3034.https:// doi.org/10.1128/AEM.68.6.3031-3034.2002

12. Barros, C. P., Grom, L. C., Guimarães, J. T., Balhazar, C. F., Rocha, R. S., Silva, R., \& Cruz, A. G. (2020). Paraprobiotic obtained by ohmic heating added in whey-grape juice drink is effective to control postprandial glycemia in healthy adults. Food Research International, 109905.https://doi.org/10.1016/j.foodres.2020.109905

13. Bhat, B., \& Bajaj, B. K. (2020). Multifarious cholesterol lowering potential of lactic acid bacteria equipped with desired probiotic functional attributes. 3 Biotech, 10(5), 116.https://doi.org/10.1007/s13205-020-02183-8

14. Chen, X., Yang, G., Song, J. H., Xu, H., Li, D., Goldsmith, J. ...\& Kelly, C. P. (2013). Probiotic yeast inhibits VEGFR signalling and angiogenesis in intestinal inflammation. PLoS One, 8(5), e64227.https://doi.org/10.1371/jour nal.pone.0064227

15. Chizhayeva, A., Oleinikova, Y., Saubenova, M., Sadanov, A., Amangeldi, A., Aitzhanova, A., \& Yelubaeva, M. (2020). Impact of probiotics and their metabolites in enhancement the functional properties of whey-based beverages. AIMS Agric Food, 5, 521-542.https://10.3934/ agrfood.2020.3.521

16. Cordeiro, B. F., Oliveira, E. R., da Silva, S. H., Savassi, B. M., Acurcio, L. B., Lemos, L., \& do Carmo, F. L. (2018). Whey protein isolate-supplemented beverage, fermented by Lactobacillus casei BL23 and Propionibacterium freudenreichii 138, in the prevention of mucositis in mice. Frontiers in Microbiology, 9, 2035.https://doi.org/1 $0.3389 /$ fmicb.2018.02035

17. De Vrese, M., \& Schrezenmeir, A. J. (2008). Probiotics, prebiotics, and synbiotics. Food Biotechnology, 166.https:// doi.org/10.1007/10_2008_097

18. Ding, W. K., \& Shah, N. P. (2008). Survival of free and microencapsulated probiotic bacteria in orange and apple juices. International Food Research Journal, 15(2), 21932. 
19. Docea, A. O., Tsatsakis, A., Albulescu, D., Cristea, O., Zlatian, O., Vinceti, M. ...\&Calina, D. (2020). A new threat from an old enemy: Re $\square$ emergence of coronavirus. International Journal of Molecular Medicine, 45(6), 1631-1643.https://doi.org/10.3892/ijmm.2020.4555

20. Enujiugha, V. N., \& Badejo, A. A. (2017). Probiotic potentials of cereal-based beverages. Critical Reviews in Food Science and Nutrition, 57(4), 790-804.https://doi.org/1 0.1080/10408398.2014.930018

21. Escamilla-Hurtado, M. L., Olguín-Lora, P., \& PradoBarragán, L. A. (1993). Lactic acid fermentation in sour corn porridge of the Tzotzil ethnic group. Revista Espanola de Ciencia y Tecnologia de Alimentos (Espana).https:// doi.org/10.1016/j.aller.2020.04.005

22. Espitia, P. J. P., Batista, R. A., Azeredo, H. M. C., \&Otoni, C. G. (2016). Probiotics and their potential applications in active edible films and coatings. Food Research International,90,42-52.https://doi:10.1016/j.foodres.20 16.10.026

23. Fernandesa, Cheryl G., Sachin K. Sonawaneb, and Arya SS. (2020). Cereal based functional beverages: a review. Journal of Microbiology, Biotechnology and Food Sciences 9.4 (2020): 914-919.https://doi.org/10.15414/ jmbfs.2018-19.8.3.914-919

24. Folkman, J. (2006). Angiogenesis. Annual Review of Medicine, 57, 1-18. https://doi.org/10.1146/annur ev.med.5 7.121304.131306

25. Folkman, J. (2007). Angiogenesis: an organizing principle for drug discovery? Nature Reviews Drug Discovery, 6(4), 273-286.https://doi.org/10.1038/nrd2115

26. Gayathri, D., \&Rashmi, B. S. (2016). Anti-cancer properties of probiotics: a natural strategy for cancer prevention. EC Nutrition, 5(4), 1191-1202.

27. Giraud, E., Gosselin, L., Marin, B., Parada, J. L., \&Raimbault, M. (1993). Purification and characterization of an extracellular amylase from Lactobacillus plantarum strain A6. Journal of Applied Bacteriology, 75(3), 276282.https://doi.org/10.1111/j.1365-2672.1993.tb02777.x

28. Gottschalk, L. (2005). Winning wheys in bars and beverages. Prepared Foods, 175(8), 71-72.

29. Granato, D., Branco, G. F., Nazzaro, F., Cruz, A. G., \&Faria, J. A. (2010). Functional foods and nondairy probiotic food development: trends, concepts, and products. Comprehensive Reviews in Food Science and Food Safety, 9(3), 292-302.https://doi.org/10.1111/j.15414337.2010.00110.x

30. Guzel-Seydim, Z. B., Kok-Tas, T., Greene, A. K., \&Seydim, A. C. (2011). Functional properties of kefir. Critical Reviews in Food Science and Nutrition, 51 (3), 261-268.https://doi.org/10.1080/10408390903579029

31. Ha, E., \&Zemel, M. B. (2003). Functional properties of whey, whey components, and essential amino acids: mechanisms underlying health benefits for active people. The Journal of Nutritional Biochemistry, 14(5), 251258.https://doi.org/10.1016/S0955-2863(03)00030-5

32. Halvorsen, R., Berstad, A., Lassen, J. F., Midtvedt, T., \&Narvhus, J. (2009). The use of probiotics for patients in hospitals. A benefit and risk assessment. Opinion of the Steering Committee of the Norwegian Scientific Committee for Food Safety. VKM Report.

33. Hamilton-Miller, J. M. T. (2003). The role of probiotics in the treatment and prevention of Helicobacter pylori infection. International Journal of Antimicrobial Agents, 22(4),
360-366.https://doi.org/10.1016/S0924-8579 (03)00153$5 \mathrm{Get}$

34. Hasler, C. M. (2002). Functional foods: benefits, concerns and challenges-a position paper from the American Council on Science and Health. The Journal of Nutrition, 132(12),3772-3781.https://doi.org/10.1093/jn/13 2.12.3772

35. Heenan, C. N., Adams, M. C., Hosken, R. W., \& Fleet, G. H. (2004). Survival and sensory acceptability of probiotic microorganisms in a nonfermented frozen vegetarian dessert. LWT-Food Science and Technology, 37(4), 461466.https://doi.org/10.1016/j.Iwt.2003.11.001

36. Hempel, S., Newberry, S. J., Maher, A. R., Wang, Z., Miles, J. N., Shanman, R., \&Shekelle, P. G. (2012). Probiotics for the prevention and treatment of antibioticassociated diarrhea: a systematic review and metaanalysis. Jama, 307(18), 1959-1969.https://doi.org/10.1 001/jama.2012.3507

37. Infusino, F., Marazzato, M., Mancone, M., Fedele, F., Mastroianni, C. M., Severino, P., \&d'Ettorre, G. (2020). Diet supplementation, probiotics, and nutraceuticals in SARS-CoV-2 infection: a scoping review. Nutrients, 12 (6), 1718.https://doi.org/10.3390/nu12061718

38. Islam, M. T., Nasiruddin, M., Khan, I. N., Mishra, S. K., Kudrat-E-Zahan, M., Riaz, T. A., ...\&Sharifi-Rad, J. (2020). A perspective on emerging therapeutic interventions for COVID-19. Frontiers in Public Health, 8.https:// doi.org/10.3389/fpubh.2020.00281

39. Jeličić, I., Božanić, R., \&Tratnik, L. (2008). Whey-based beverages-a new generation of dairy products. Mljekarstvo, 58(3), 257-274.

40. Kahouli I, Malhotra M, Alaoui-Jamali MA, Prakash S. (2015) In-vitro characterization of the anti-cancer activity of the probiotic bacterium Lactobacillus fermentum NCIMB 5221 and potential against colorectal cancer cells. Journal of Cancer Science Therapy, 7:224e35.https://doi.org/10.4172/1948-593X.1000132

41. Karimi, G., Sabran, M. R., Jamaluddin, R., Parvaneh, K., Mohtarrudin, N., Ahmad, Z. ...\&Khodavandi, A. (2015). The anti-obesity effects of Lactobacillus casei strain Shirotaversus Orlistat on high fat diet-induced obese rats. Food \& Nutrition Research, 59(1), 29273.https:// doi.org/10.3402/fnr.v59.29273

42. Kassem, J. M. (2015). Future challenges of whey proteins. International Journal of Dairy Science, 10(4), 139159.https://doi.org/10.3923/ijds.2015.139.159

43. Kechagia, M., Basoulis, D., Konstantopoulou, S., Dimitriadi, D., Gyftopoulou, K., Skarmoutsou, N., \&Fakiri, E. M. (2013). Health benefits of probiotics: a review. International Scholarly Research Notices, 2013.https://doi.org/10.5402/2013/481651

44. Kerry, R. G., Patra, J. K., Gouda, S., Park, Y., Shin, H. S., \& Das, G. (2018). Benefaction of probiotics for human health: A review. Journal of food and drug analysis, 26 (3), 927-939.https://doi.org/10.1016/j.jfda.2018.01.002

45. Khalesi, S., Bellissimo, N., Vandelanotte, C., Williams, S., Stanley, D., \& Irwin, C. (2019). A review of probiotic supplementation in healthy adults: helpful or hype? European Journal of Clinical Nutrition, 73(1), 2437.https://doi.org/10.1038/s41430-018-0135-9

46. Khan, S., Amin, N., Ansari, Z., \&Majumder, D. R. (2015). Whey: Waste to health and wealth. International Journal 
of Current Microbiological Application Science, 2, 245253.

47. Kitabatake, N., Gimbi, D. M., \&Oi, Y. (2003). Traditional non-alcoholic beverage, Togwa, in East Africa, produced from maize flour and germinated finger millet. International Journal of Food Sciences and Nutrition, 54(6), 447455.https://doi.org/10.1080/09637480120092053

48. Kobyliak, N., Conte, C., Cammarota, G., Haley, A. P., Styriak, I., Gaspar, L. ...\&Kruzliak, P. (2016). Probiotics in prevention and treatment of obesity: a critical view. Nutrition \& metabolism, 13(1), 1-13.https:// doi.org/10.1186/s12986-016-0067-0

49. Kristensen, N. B., Bryrup, T., Allin, K. H., Nielsen, T., Hansen, T. H., \& Pedersen, O. (2016). Alterations in fecalmicrobiota composition by probiotic supplementation in healthy adults: a systematic review of randomized controlled trials. Genome medicine, 8(1), 1-11.https:// doi.org/10.1186/s13073-016-0300-5

50. Kröckel L (2006). Use of Probiotic Bacteria in Meat Products. Fleischwirtschaft.86:109-113.

51. Kumari, J., \& Morya, S. (2021). Celiac disease: An epidemiological condition: Insight on gluten free diet, significance and regulatory recommendations. ThePharma Innovation Journal.2021; 10(5):641-654.

52. Küster-Boluda, I., \& Vidal-Capilla, I. (2017). Consumer attitudes in the election of functional foods. Spanish Journal of Marketing-ESIC, 21, 65-79.https://doi.org/10.1016/ j.sjme.2017.05.002

53. Lappa, I. K., Papadaki, A., Kachrimanidou, V., Terpou, A., Koulougliotis, D., Eriotou, E., \&Kopsahelis, N. (2019). Cheese Whey Processing: Integrated Biorefinery Concepts and Emerging Food Applications. Foods. https:// doi.org/10.3390/foods 8080347

54. Laureys, D., \& De Vuyst, L. (2014). Microbial species diversity, community dynamics, and metabolite kinetics of water kefir fermentation. Applied and Environmental Microbiology, 80(8), 2564-2572.https://doi.org/10.1128/AE M.03978-13

55. Leatherhead Food Research. (2011). Future Directions for the Global Functional Foods Market.

56. Leung, A. K., Leung, A. A., Wong, A. H., \& Hon, K. L. (2019). Travelers'diarrhea: a clinical review. Recent $\mathrm{Pa}$ tents on Inflammation \& Allergy Drug Discovery, 13(1), 3848.https://doi.org/10.2174/1872213X13666190514105054

57. Lewis, B. B., Buffie, C. G., Carter, R. A., Leiner, I., Toussaint, N. C., Miller, L. C., ... \&Pamer, E. G. (2015). Loss of microbiota-mediated colonization resistance to Clostridium difficile infection with oral vancomycin compared with metronidazole. The Journal of infectious diseases, 212(10), 1656-1665.https://doi.org/10.1093/infdis/jiv256

58. Lin, M. Y., \& Chen, T. W. (2000). Reduction of cholesterol by Lactobacillus acidophilus in culture broth. Journal of Food and Drug Analysis, 8(2).

59. Lloyd-Price, J., Abu-Ali, G., \&Huttenhower, C. (2016). The healthy human microbiome. Genome medicine, 8(1), 111.https://doi.org/10.1186/s13073-016-0307-y

60. Markowiak, P., \&Śliżewska, K. (2017). Effects of probiotics, prebiotics, and synbiotics on human health. Nutrients, 9(9), 1021. https://doi.org/10.3390/nu9 091021

61. Marsh, A. J., Hill, C., Ross, R. P., \& Cotter, P. D. (2014). Fermented beverages with health-promoting potential:
Past and future perspectives. Trends in Food Science \& Technology, 38(2),113-124.https://doi.org/10.1016/j.tifs.20 14.05 .002

62. Martínez Leal, J., Valenzuela Suárez, L., Jayabalan, R., Huerta Oros, J., \& Escalante-Aburto, A. (2018). A review on health benefits of kombucha nutritional compounds and metabolites. CyTA-Journal of Food, 16(1), 390399.https://doi.org/10.1080/19476337.2017.1410499

63. Masoumi, S. J., Mehrabani, D., Saberifiroozi, M., Fattahi, M. R., Moradi, F., \&Najafi, M. (2021). The effect of yogurt fortified with Lactobacillus acidophilus and Bifidobacterium $\mathrm{sp}$. probiotic in patients with lactose intolerance. Food Science \& Nutrition, 9(3), 1704-1711.https://doi.org/1 $0.1002 / f s n 3.2145$

64. McFarland, L. V. (2006). Meta-analysis of probiotics for the prevention of antibiotic associated diarrhea and the treatment of Clostridium difficile disease. American Journal of Gastroenterology, 101(4), 812-822.https://doi.org/1 0.1111/j.1572-0241.2006. 00465.x

65. Morya, S., \& Danquah-Amoah, A. (2018). Impact of Whey Derived Bio-Active Components on Resolving Human Health Issues: As Nutraceuticals. In Food Technology and Nutrition, 99, 15.

66. Morya, S., Chandra, R., \& Thompkinson, D. K. (2017b). Organoleptic evaluation of low fat probiotic (Lactobacillus acidophilus) beverage prepared by whey and sorghum. The Pharma Innovation, 6 (7, Part C), 153.

67. Morya, S., Chandra, R., \&Seelam, B. S. (2017a). Microbial characteristics of whey and sorghum based low fat probiotic beverage. International Journal of Chemical Studies, 5(4), 403-406.

68. Moura, C. S., Lollo, P. C. B., Morato, P. N., Esmerino, E. A., Margalho, L. P., Santos-Junior, V. A., ... \& AmayaFarfan, J. (2016). Assessment of antioxidant activity, lipid profile, general biochemical and immune system responses of Wistar rats fed with dairy dessert containing Lactobacillus acidophilus La-5. Food Research International, 90,275-280.https://doi.org/10.1016/j.foodres.201 6.10.0 42

69. Muyanja, C. M. B. K., Narvhus, J. A., Treimo, J., \&Langsrud, T. (2003). Isolation, characterisation and identification of lactic acid bacteria from bushera: a Ugandan traditional fermented beverage. International Journal of Food Microbiology, 80(3), 201-210.https://doi.org/10.1016/ S0168-1605(02)00148-4

70. Onwulata, C., \&Tomasula, P. (2004). Whey texturization: A way forward. Food Technology-Champaign then Chicago-, 58, 50-55. q

71. Osimani, A., Garofalo, C., Aquilanti, L., Milanović, V., \&Clementi, F. (2015). Unpasteurised commercial boza as a source of microbial diversity. International Journal of Food Microbiology, 194, 62-70.https://doi.org/10.1016/ j.ijfoodmicro.2014.11.011

72. Özer, B. H., \& Kirmaci, H. A. (2010). Functional milks and dairy beverages. International Journal of Dairy Technology, 63(1), 1-15.https://doi.org/10.1111/j.1471-0307.20 09.00547.x

73. Özer, B., Uzun, Y. S., \& Kirmaci, H. A. (2008). Effect of microencapsulation on viability of Lactobacillus acidophilus LA $\square 5$ and Bifidobacterium bifidum BB $\square 12$ during Kasar cheese ripening. International Journal of Dairy Technology, 61(3), 237-244.https://doi.org/10.1111/j.1471- 
0307.2008.00408.x

74. Pamer, E. G. (2016). Resurrecting the intestinal microbiota to combat antibiotic-resistant pathogens. Science, 352 (6285), 535-538.https://doi.org/10.1126/science.aad9382

75. Pérez-Cobas, A. E., Moya, A., Gosalbes, M. J., \&Latorre, A. (2015). Colonization resistance of the gut microbiota against Clostridium difficile. Antibiotics, 4(3), $337-$ 357.https://doi.org/10.3390/antibiotics4030337

76. Pescuma, M., Hébert, E. M., Mozzi, F., \& De Valdez, G. F. (2010). Functional fermented whey-based beverage using lactic acid bacteria. International Journal of Food Microbiology, 141(1-2), 73-81.https://doi.org/10.1016/j.ijfoodmic ro.2010.04.011

77. Pinto, J. M., Sousa, S., Rodrigues, D. M., Malcata, F. X., Duarte, A. C., Rocha-Santos, T. A. ...\& Gomes, A. M. (2017). Effect of probiotic co-cultures on physico-chemical and biochemical properties of small ruminants' fermented milk. International Dairy Journal, 72, 29-35.https:// doi.org/10.1016/j.idairyj.2017.04.005

78. Plaza-Díaz, J., Fernández-Caballero, J. Á., Chueca, N., García, F., Gómez-Llorente, C., Sáez-Lara, M. J. ...\& Gil, Á. (2015). Pyrosequencing analysis reveals changes in intestinal microbiota of healthy adults who received a daily dose of immunomodulatory probiotic strains. Nutrients, 7 (6), 3999-4015.

79. Qadir, M. I. (2015). Phage Therapy: a modern tool to control bacterial infections. Pakistan journal of pharmaceutical sciences, 28(1).

80. Raghuwanshi, S., Misra, S., \&Bisen, P. S. (2015). Indian perspective for probiotics: A review. Indian Journal of Dairy Science, 68(3), 195-205.

81. Raghuwanshi, S., Misra, S., Sharma, R., \&Bisen, P. (2018). Probiotics: nutritional therapeutic tool. Journal of Probiotics Health, 6, 2.https://doi.org/10.4172/23298901.1000194

82. Ranadheera, C. S., Vidanarachchi, J. K., Rocha, R. S., Cruz, A. G., \&Ajlouni, S. (2017). Probiotic delivery through fermentation: dairy vs. non-dairy beverages. Fermentation, 3(4), 67.https://doi.org/10.3390/ferment ation3040067

83. Rao, S. C., Athalye-Jape, G. K., Deshpande, G. C., Simmer, K. N., \&Patole, S. K. (2016). Probiotic supplementation and late-onset sepsis in preterm infants: a metaanalysis. Pediatrics, 137(3).https://doi.org/10.1542/ peds.2015-3684

84. Saarela, M., Virkajärvi, I., Alakomi, H. L., Sigvart-Mattila, P., \&Mättö, J. (2006). Stability and functionality of freezedried probiotic Bifidobacterium cells during storage in juice and milk. International Dairy Journal, 16(12), 14771482.https://doi.org/10.1016/j.idairyj.2005.12.007

85. Salmeron, I., Thomas, K., \& Pandiella, S. S. (2015). Effect of potentially probiotic lactic acid bacteria on the physicochemical composition and acceptance of fermented cereal beverages. Journal of Functional Foods, 15, 106115.https://doi.org/10.1016/j.jff.2015.03.012

86. Sazawal, S., Hiremath, G., Dhingra, U., Malik, P., Deb, S., \& Black, R. E. (2006). Efficacy of probiotics in prevention of acute diarrhoea: a meta-analysis of masked, randomised, placebo-controlled trials. The Lancet infectious diseases, 6(6), 374-382.https://doi.org/10.1016/S1473-3099 (06)70495-9

87. Scott, K. P., Jean-Michel, A., Midtvedt, T., \& van Hemert,
S. (2015). Manipulating the gut microbiota to maintain health and treat disease. Microbial ecology in health and disease, 26(1),25877.https://doi.org/10.3402/mehd.v26.25 877

88. Setta, M. C., Matemu, A., \&Mbega, E. R. (2020). Potential of probiotics from fermented cereal-based beverages in improving health of poor people in Africa. Journal of Food Science and Technology, 1-12.https://doi.org/10.1007/ s13197-020-04432-3

89. Shori, A. B. (2012). Comparative study of chemical composition, isolation and identification of micro-flora in traditional fermented camel milk products: Gariss, Suusac, and Shubat. Journal of the Saudi Society of Agricultural Sciences, 11(2), 79-88. https://doi.org/10.1016/j.jssas.20 11.12.001

90. Smit, G., Smit, B. A., \& Engels, W. J. (2005). Flavour formation by lactic acid bacteria and biochemical flavour profiling of cheese products. FEMS microbiology reviews, 29(3), 591-610.https://doi.org/10.1016/j.fmrre.200 5.04 .002

91. Song, D., Ibrahim, S., \& Hayek, S. (2012). Recent application of probiotics in food and agricultural science. Probiotics, 10, 1-34.https://doi.org/105772/3444

92. Song, S., Lee, S. J., Park, D. J., Oh, S., \& Lim, K. T. (2016). The anti-allergic activity of Lactobacillus plantarum L67 and its application to yogurt. Journal of Dairy Science, 99(12), 9372-9382.https://doi.org/10.3168/jds.201611809

93. Sultan, S., Huma, N., Butt, M. S., Aleem, M., \& Abbas, M. (2018). Therapeutic potential of dairy bioactive peptides: A contemporary perspective. Critical Reviews in Food Science and Nutrition, 58(1), 105-115.https://doi.org/10.10 80/10408398.2015.1136590

94. Susli, H. (1956). New type of whey utilization: A lactomineral table beverage. Proc. 14th Int. Dairy Congress, (Pt. 2), 477.

95. Tabbers, M. M., Chmielewska, A., Roseboom, M. G., Crastes, N., Perrin, C., Reitsma, J. B. \&Benninga, M. A. (2011). Fermented milk containing Bifidobacteriumlactis DN-173 010 in childhood constipation: a randomized, double-blind, controlled trial. Pediatrics, 127(6), e1392e1399.https://doi.org/10.1542/peds.2010-2590

96. Takeda, S., Hidaka, M., Yoshida, H., Takeshita, M., Kikuchi, Y., Tsend-Ayush, C. ...\&Kurokawa, M. (2014). Antiallergic activity of probiotics from Mongolian dairy products on type I allergy in mice and mode of antiallergic action. Journal of Functional Foods, 9, 60-69.https:// doi.org/10.1016/j.jff.2014.04.013

97. Troost, F. J., Steijns, J., Saris, W. H., \&Brummer, R. J. M. (2001). Gastric digestion of bovine lactoferrin in vivo in adults. The Journal of nutrition, 131(8), 2101-2104.https:// doi.org/10.1093/jn/131.8.2101

98. Valero-Cases, E., Cerdá-Bernad, D., Pastor, J. J., \&Frutos, M. J. (2020). Non-dairy fermented beverages as potential carriers to ensure probiotics, prebiotics, and bioactive compounds arrival to the gut and their health benefits. Nutrients, 12(6), 1666. https://doi.org/10.3390/nu1206 1666

99. Vedamuthu, E. R. (2013). 19 Other fermented and culturecontaining milks. Manufacturing yogurt and fermented milks, 393.https://doi.org/10.1002/9781118481301

100.Verbeke, W., Scholderer, J., \&Lähteenmäki, L. (2009). 


\begin{abstract}
Consumer appeal of nutrition and health claims in three existing product concepts. Appetite, 52(3), 684-692. https://doi.org/10.1016/j.appet.2009.03.007

101.Vidya, S., \&Thiruneelakandan, G. (2015). Probiotic potentials of lactobacillus and its anti-cancer activity. International Journal of Current Research, 7(9), 2068020684.
\end{abstract}

102.Von Wright, A., \& Axelsson, L. (2019). Lactic acid bacteria: an introduction (pp. 1-16). CRC Press. https:// doi.org/10.1201/9780429057465

103.Walsh, H., Ross, J., Hendricks, G., \&Guo, M. (2010). Physico-chemical properties, probiotic survivability, microstructure, and acceptability of a yogurt $\square$ like symbiotic oats -based product using pre $\square$ polymerized whey protein as a gelation agent. Journal of Food Science, 75(5), M327-
M337.https://doi.org/10.1111/j.1750-3841.2010.01637.x

104.Wang, J., Guo, Z., Zhang, Q., Yan, L., Chen, W., Liu, X. M., \& Zhang, H. P. (2009). Fermentation characteristics and transit tolerance of probiotic Lactobacillus casei Zhang in soymilk and bovine milk during storage. Journal of Dairy Science, 92(6), 2468-2476.https://doi.org/1 $0.3168 / j \mathrm{jds} .2008-1849$.

105.Wootton-Beard, P. C., \& Ryan, L. (2011). Improving public health? The role of antioxidant-rich fruit and vegetable beverages. Food Research International, 44(10), 31353148.https://doi.org/10.1159/000051926

106. Yerlikaya, O. (2014). Starter cultures used in probiotic dairy product preparation and popular probiotic dairy drinks. Food Science and Technology, 34(2), 221229.https://doi.org/10.1159/000051926 